IJMS 16 (1), 213-228 (2009)

\title{
INFORMATION TECHNOLOGY SOPHISTICATION, MANAGEMENT ACCOUNTING INFORMATION PROVISION AND COMPUTER-BASED INFORMATION SYSTEMS SUCCESS
}

\author{
NOOR AZIZI ISMAIL \\ College of Business \\ Universiti Utara Malaysia
}

\begin{abstract}
The emergence of a knowledge-based economy, consequent to the advancement in information technology (IT), puts more pressure on businesses to generate information to quickly create technologically advanced and customised products at relatively low costs. Firms, particularly small and medium sized enterprises (SMEs), need to understand and rely more on strategic accounting information and recognise the potential that IT has in generating these information. This paper reports the results of a study which offers an explanation for the relationship between IT sophistication and computer-based information systems (CBIS) success of SMEs, by incorporating into the model the provision of management accounting information (MAI provision). Data were collected from 214 SMEs in Malaysia by way of a questionnaire-based survey. The results showed that IT sophistication is a determinant of MAI provision, which in turn, is a determinant of CBIS success. Overall, the results suggested that MAI provision plays a mediating role in the relationship between IT sophistication and CBIS success of SMEs. An interpretation of these results is that those SMES which employ sophisticated IT can generate sufficient management accounting information and thereby improve their CBIS.
\end{abstract}

Keywords: Information technology; information systems; management accounting system; accounting information systems; small and medium enterprises.

\begin{abstract}
ABSTRAK
Kemunculan ekonomi berasaskan pengetahuan, hasil daripada perkembangan teknologi maklumat telah memberi tekanan kepada firma-firma perniagaan
\end{abstract}


bagi menjana maklumat yang dapat membantu mereka menghasilkan produk berteknologi tinggi serta berupaya mengikut kehendak pelanggan pada harga yang rendah. Firma-firma perniagaan terutama yang bersaiz kecil dan sederhana perlu memahami serta menggunakan maklumat perakaunan strategik dalam pembuatan keputusan perniagaan mereka. Selain itu, mereka juga perlu mengenal pasti potensi yang ditawarkan oleh teknologi maklumat bagi menjana maklumat tersebut. Artikel ini melaporkan dapatan daripada satu kajian yang cuba menjelaskan hubungan antara kecanggihan teknologi maklumat dan kejayaan sistem maklumat berasaskan komputer dalam kalangan firma-firma yang bersaiz kecil dan sederhana dengan memasukkan elemen peruntukan maklumat perakaunan pengurusan dalam model kajian. Data kajian telah dikutip daripada 214 firma bersaiz kecil dan sederhana di Malaysia dengan menggunakan kaedah soal selidik. Dapatan kajian mendapati kecanggihan teknologi maklumat merupakan penentu kepada peruntukan maklumat perakaunan pengurusan, yang kemudiannya menentukan pula kejayaan sesebuah sistem maklumat berasaskan komputer. Secara keseluruhannya, dapatan kajian ini mencadangkan bahawa peruntukan maklumat perakaunan pengurusan memainkan peranan sebagai perantara dalam hubungan antara kecanggihan teknologi maklumat dan sistem maklumat berasaskan komputer. Interpretasi kepada dapatan kajian ini ialah firma-firma bersaiz kecil dan sederhana yang menggunakan teknologi maklumat canggih akan berupaya menjana maklumat perakaunan pengurusan yang mencukupi dan seterusnya meningkatkan keupayaan sistem maklumat berasaskan komputer yang digunakan.

\section{INTRODUCTION}

Information technology (IT) has revolutionised business practices and plays a central part in business strategies (Brecht \& Martin, 1996). Technological advancement has also changed the role of accountants and accounting information systems (AIS) (Mauldin \& Ruchala, 1999). Modern AIS is viewed in a much broader perspective with added emphasis on the economies of business operations and strategic management (Ismail \& King, 2007). As an economy based on knowledge emerges, information is essential for the survival of any organisation (de Guinea, Kelly, \& Hunter, 2005). There is more pressure on firms to generate information to quickly create technologically advanced and customised products at relatively low costs (Hunter \& Long, 2002). Businesses, particularly small and medium sized enterprises (SMEs), need to understand and rely more on strategic information and recognise the potential that IT has in generating those information (El Louadi, 1998). This is important as the capacity of a country's economy to adapt 
to the changing business environment has been linked to the flexibility and responsiveness of its SMEs (Hunter \& Long, 2003). Governments and economists also view SMEs as the mechanism through which national growth is created (Pollard \& Hayne, 1997). Despite this, there is still a lack of understanding of the relationship between IT sophistication, management accounting information provision, and computer-based information systems (CBIS) success, especially in the context of SMEs.

The Malaysian Small and Medium Industries Development Corporation (SMIDEC) defined SMEs in manufacturing, manufacturing-related services, and agro-based industries as enterprises with full-time employees not exceeding 150 or with annual sales turnover not exceeding RM25 million. For those in the service and primary agriculture sectors, SMEs are defined as enterprises with full-time employees not exceeding 50 or with annual sales turnover not exceeding RM5 million. In 2006, the Malaysian National SME Development Council reported that the SME sector comprises $99.2 \%$ of total business establishments and employs more than 5.6 million workers. The SME sector also contributed 32\% of the real gross domestic product (GDP) and 19\% of the total export value of the country. In addition, Ismail and King (2005) reported that manufacturing SMEs represent about 91\% of the total manufacturing establishments in Malaysia. These data demonstrated that SMEs are essential to the prosperity of Malaysia.

To achieve the status of a developed nation by the year 2020, Malaysia is rapidly shifting its orientation toward an IT-based environment. This effort is consistent with the increasing globalisation of demand and the utilisation of IT as a competitive weapon. Inspite of the various programmes established by the government, the extent, mode, and quality of IT adoption among Malaysian SMEs is still an issue of great concern (Ismail, Abdullah, \& Tayib, 2003). Thus, on grounds of both economic magnitude and importance in achieving Malaysia's goal of becoming a fully developed and industrialised nation by the year 2020, a strong case can be made for focusing on IT and information provision in SMEs.

Pursuing these ideas further, this study sought to examine the mediating effect of information provision in the relationship between IT sophistication and CBIS success within the specific context of SMEs. The type of information in this study was restricted to management accounting (MA) information, in which management accounting system (MAS) is an important component of a modern CBIS (Mitchell, Reid, 
\& Smith, 2000). The SME setting also provides a relatively focused insight into the management needs for MA information, and IT as an information processing mechanism.

\section{LITERATURE REVIEW}

\section{Information Needs of SMEs}

SMEs are under particular pressure to make accurate decisions given the competitive conditions under which they typically operate (El Louadi, 1998). Central to decision-making "is the set of information on which decisions are predicated...the scale, scope, quality and timeliness of information all have a crucial bearing on the decisions managers make" (Mitchell et al., 2000: 15). With regard to accounting information, existing literature provided little evidence of MAS development within SMEs. There is considerable evidence to suggest that within SME financial accounting has remained the principal source of information for its management (Marriot \& Marriot, 2000). These studies suggested that financial awareness among managers of SMEs varies considerably and the use of computers for the preparation of MA information is not at its full potential.

On the contrary, Mitchell et al. (2000) and Ismail and King (2005) found extensive use of MA information in SMEs. Similarly, Perren and Grant (2000) suggested that most SMEs acquire information and achieve effective control via informal means, and that decision-making can be more sophisticated than anticipated. The authors argued that this apparent contradiction stems largely from the researchers' differing paradigms rather than any differences in reality. Their argument is supported by the International Federation of Accountants (2006), which reported that despite the variations in use of accounting information among SMEs, there is evidence to suggest that SMEs are aware of the importance of accounting information and use it for a variety of purposes.

\section{IT in SMEs}

Existing IT literature provided conflicting evidence on how IT is used to support information requirements in SMEs. Although results from past studies indicated that IT adoption has grown tremendously within SMEs, there is considerable evidence to suggest that very few of the resulting systems have had significant impact on the way the management make 
decisions (Ravarini, Tagliavini, \& Buonanno, 2002). There is thus limited evidence that IT is used to support decision-making. The most prevalent applications in SMEs are transactional in nature. A recent study by Temtime, Chinyoka, and Shunda (2003) further confirmed that computers in SMEs are mainly used for administrative and operational tasks. Fuller (1996) argued that the key problem of the lack of strategic IT usage in SMEs relates to the relatively poor fit between what the software tools are offering and what is needed, with neither the users nor the suppliers being in a strong position for communicate with each other. However, results from several studies showed some support for the idea that IT can help SMEs develop and implement business strategy. For example, Cragg, King, and Hussin (2002), Raymond and St-Pierre (2005), and Ismail and King (2005) revealed SMEs need to align IT strategy with business strategy in order to increase profitability.

\section{CBIS Success in SMEs}

A large body of IS research has also attempted to identify factors leading to the success of CBIS implementation. Stemming from this, advice has been offered to SMEs on how to approach computerisation (Hunton \& Flowers, 1997). However, IS researchers encounter difficulty in isolating a definitive body of contributing factors since the measure of CBIS success varies considerably among studies. Among the popular measures of CBIS success include user satisfaction, system usage, perceived system effectiveness, individual impact, and organisational impact. Six major factors identified to contribute to CBIS success include extent of computerisation, top management support, users' IT knowledge, user participation, vendor support, and consultant effectiveness. However, the results of these studies are ambiguous and contradictory due to the different measures of CBIS success (Ismail \& King, 2005).

\section{THEORETICAL BACKGROUND}

IT implementation in SMEs has long been an issue of great concern for many IS researchers. Among the issues investigated are: factors motivating and inhibiting IT adoption; factors affecting CBIS success; factors affecting the level of IT sophistication; IT alignment; IT and accounting information provision; and IT and performance. However, very few of these studies had considered the impact of IT on the individual, system, and organisation in a single setting. There is also a lack of understanding on the relationship between IT sophistication, information provision, 
and CBIS success. Therefore, rather than continuing to replicate prior research, this study has included variables relating to IT sophistication, provision of MA information (hereafter referred to as MAI provision), and CBIS success to further understand how IT affects the provision of a specific type of information and ultimately CBIS success of SMEs. To address the issue, this study firstly examined the relationship between IT sophistication and MAI provision, and then examined the relationship between MAI provision and CBIS success. Figure 1 depicts the research model. The hypotheses of this model are presented in the following discussion.

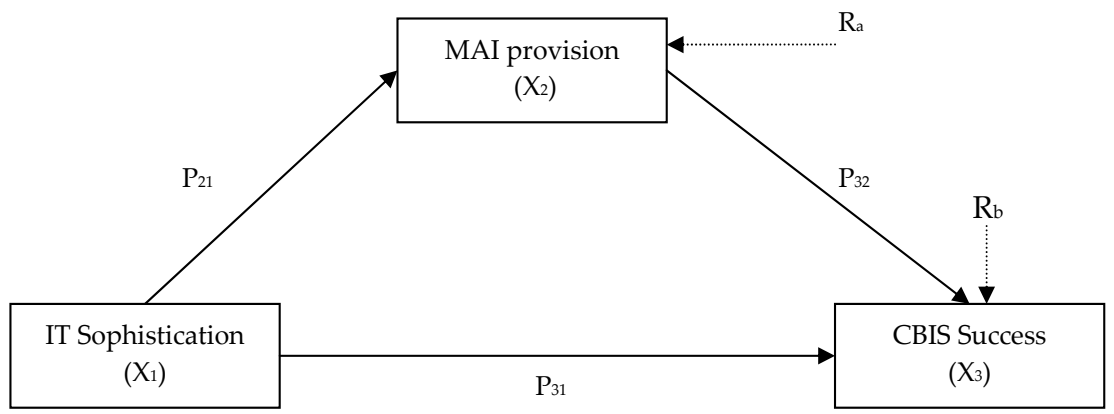

Figure 1: The research model

Anecdotal evidences suggested that IT can bring many benefits to organisations. However, IS researchers have struggled to show a direct impact of IT on CBIS success (Shin, 2001). Results of prior studies showed inconclusive findings. Whilst some studies found direct relationships between IT sophistication and CBIS success, others revealed weak or no relationships between the two variables. DeLone and McLean (1992) suggested that CBIS success should not be measured on a piecemeal basis, but from the overall perspectives of the individual, system, and organisation. Following contingency theory, several IS researchers argued that IT is an essential tool to increase CBIS processing capabilities, but needs to be coupled with other organisational factors to have a greater impact on overall CBIS success (Raymond \& St-Pierre, 2005). Ismail and King (2005) confirmed this argument when they found that IT would have a more significant impact on performance when it is aligned with other organisational factors. Due to the lack of prior research and empirical evidence in this area, particularly any that incorporates MAI provision, our prediction is tentative. The relationship is formally stated in its null form: 
$\mathrm{H}_{1}$ : There is no relationship between IT sophistication and CBIS success

Information processing theory postulated that IT is one of the mechanisms that can be used to increase CBIS processing capabilities. Huber (1990) theoretically argued that "use of advanced IT leads to more available and more quickly retrieved information, including external information, internal information, and previously encountered information, and thus leads to increased information accessibility" (p. 65). Daft and Lengel (1986) also placed particular emphasis on IT as a means by which organisations reduce uncertainty. El Louadi (1998) confirmed that IT sophistication has a direct effect on the amount of information provided. Following these ideas further, we argued that as IT sophistication increases, managers have greater accessibility to MA information to assist them in making effective business decisions:

$\mathrm{H}_{2}$ : There is a positive relationship between IT sophistication and MAI provision

MA information can give benefits to firms in two ways (Mitchell et al., 2000). Firstly, MA information can help firms manage shortterm problems by appropriate monitoring and control. Secondly, MA information can help businesses integrate operational considerations within long-term strategic plans. Porter (1985) argued that in order for an organisation to survive and succeed in a competitive market, it must scan and monitor its environment with respect to threats from potential competitors, threats from substitute products and services, the nature and intensity of competition within the industry, and the bargaining power of suppliers and customers. To deal with these threats, a firm can use MA information to scan its environment and identify any changes in the industry and in the competitors' strategies. MA information can help assess the attributes, price, and costs of the substitute products in the market. Following the task-technology fit theory, it is plausible to argue that firms need to employ sophisticated technology to generate strategic MA information in order to make the right decisions, which would eventually have a positive impact on overall success of CBIS. Based on the above discussions, the final hypothesis is formally stated as follows:

$\mathrm{H}_{3}$ : There is a positive relationship between MAI provision and CBIS success

The discussion of hypotheses two and three support the argument that MAI provision plays a mediating role in the relationship between IT 
sophistication and CBIS success. When the relationship between the two variables exists, at least partly via a third variable, then the third variable plays a mediating role in the relationship between the other two variables. For this study, support for hypotheses two and three would suggest that managers' use of MA information plays a mediating role in the relationship between IT sophistication and CBIS success (see Figure 1).

\section{RESEARCH METHODS}

SMEs in this study were defined as any manufacturing firm with between 20 and 150 employees. The number of employees is the most commonly used international definition in the literature, since in some cultures, small firms are reluctant to disclose specific financial details (Ismail \& King, 2005). Very small firms (with less than 20 employees) were excluded to increase the probability of computerised firms and firms that to some degree adopted strategic MAS information. The manufacturing sector was selected because it is considered informationintensive and can provide the widest usage of CBIS due to the presence of all major business functions.

A cross-sectional field survey was then used to collect empirical data from Malaysian SMEs. The design of the survey and collection procedures followed Dillman's (1978) recommendations and guidelines. The Federation of Malaysian Manufacturer's database provided a total of 771 addresses of firms as defined in this study. A total of so addresses were used for the pilot survey, and the rest were used for the main survey. The questionnaire was refined in two stages prior to the actual survey: pre-testing with academics and firm managers, followed by pilot testing with firm managers. The survey instrument was directed to the individual in the SMEs who could answer questions regarding accounting and IT issues: either the owner of the firms or the employee primarily responsible for CBIS. A total of 214 usable questionnaires were eventually returned, representing a $29 \%$ response rate.

\section{Instrument Construction}

The three constructs, as depicted in Figure 1, were measured in this study: IT sophistication, MAI provision, and CBIS success. The measurements used were adapted from previously validated measures. Firstly, in identifying the impact of IT on organisations, a number of researchers 
have attempted to characterise this concept. Among the popular measures include types of IT-based systems, applications portfolio, processing mode, and stages of IT development. In this study, IT sophistication was measured by the number of computer applications portfolio employed by the firms. It is plausible to assume that the more sophisticated the computer applications portfolio employed by the firm, the more sophisticated the information generated by the firm's CBIS. Respondents were asked to indicate which of the 18 applications portfolio (i.e. accounts receivable, accounts payable, general ledger, payroll, billing, inventory, order entry, purchasing, financial accounting, cost accounting, financial analysis, budgeting, personnel management, production planning and control, budget variances, production variances, project management, and modelling) were employed in their respective firm's CBIS.

The definition of AIS has evolved over the years from one focusing on more formal, financially quantifiable information to one that embraces a much broader scope of information. In this study, the measurement used for MAI provision was adapted from Chenhall and Morris (1986). The instrument has been modified and validated in the specific context of SMEs by Ismail and King (2005). The construct was measured using 19item scales, namely frequency of reporting, temporal reports, summary reports-organization, speed of reporting, sectional reports, summary reports-sections, future events, non-financial production, immediate reporting, automatic receipt, decisional models, organisational effect, precise targets, effects of events on functions, non-financial market, sub-unit interaction, what-if analysis, non-economic information, and external information. The respondents were requested to state the extent to which their CBIS supported each of the 19 MAI characteristics on a 5-point scale from 1 (information not available) to 5 (information extensively available). The Cronbach alpha statistic for the overall scale for MAI provision was 0.94 .

Finally, DeLone and McLean's (1992) model was chosen to represent CBIS success. Several reasons justified the selection of this model. Firstly, the model addresses CBIS benefits at all three levels, i.e. the individual (system use, user satisfaction, and individual impact), system (systems quality and information quality), and organisation (organisational impact), and thus best reflects the evaluation of IT impact on firm's CBIS. Secondly, the model had been used as a basis for empirical research, refined and expanded by a number of researchers. Al-Mushayt (2000) developed six questions to measure organisational CBIS success based on DeLone and McLean's taxonomy. The results indicated that the 
model is valid, unidimensional, and reliable, and can be summated. Using similar questions, the respondents were asked, on a 5-point scale, to indicate the level of success of their CBIS in terms of system quality, information quality, information use, user satisfaction, individual impact, and organisational impact. The Cronbach alpha statistic for the overall scale for CBIS success was 0.88 . Table 1 presents the descriptive statistics for the variables.

Table 1: Descriptive Statistics

\begin{tabular}{lllllll}
\hline Variables & Mean & SD & \multicolumn{2}{c}{ Actual Range } & \multicolumn{2}{c}{ Theoretical Range } \\
& & & Min & Max & Min & Max \\
\hline $\begin{array}{l}X_{1} \text { IT Sophistica- } \\
\text { tion }\end{array}$ & 8.96 & 3.68 & 0 & 18 & 0 & 18 \\
X $_{2}$ MAI Provision & 2.88 & 0.73 & 1 & 5 & 1 & 5 \\
X $_{3}$ CBIS Success & 3.40 & 0.58 & 2 & 5 & 1 & 5 \\
\hline
\end{tabular}

\section{RESULTS}

The results in Table 2 provide preliminary support for the rejection of hypothesis $\mathrm{H}_{1}$ since the correlation between IT sophistication $\left(\mathrm{X}_{1}\right)$ and CBIS success $\left(X_{3}\right)$ is positive and significant. This result is consistent with the anecdotal evidence which suggested that organisations can improve CBIS success with more sophisticated IT. Since the correlations between IT sophistication $\left(X_{1}\right)$ and MAI provision $\left(X_{2}\right)$, and MAI provision $\left(X_{2}\right)$ and CBIS success $\left(X_{3}\right)$ are positive and significant, the results provided preliminary support for hypotheses $\mathrm{H}_{2}$ and $\mathrm{H}_{3}$ as well. It was also observed that the relationship between $X_{2}$ and $X_{3}\left(r_{23}=0.365\right)$ is stronger than the relationship between $X_{1}$ and $X_{3}\left(r_{13}=0.188\right)$, which suggested that MAI provision has greater impact on CBIS success than IT sophistication.

Table 2: Correlation Matrix

\begin{tabular}{llll}
\hline & $\mathrm{X} 1$ & $\mathrm{X}_{2}$ & $\mathrm{X}_{3}$ \\
\hline X1 IT Sophistication & 1.000 & $0.221^{*}$ & $0.188^{*}$ \\
X $_{2}$ MAI Provision & & 1.000 & $0.365^{*}$ \\
$X_{3}$ Performance & & & 1.000 \\
\hline
\end{tabular}

* Correlation is significant at the 0.01 level (2-tailed) 
A path analytic technique was used to test the model of the study shown in Figure 1. In the model, the relationships between the variables were specified by a series of path coefficients $\left(\mathrm{P}_{\mathrm{ij}}\right)$ which are equivalent to standardised beta coefficients $(\beta)$. The $R_{n}(n=a$, and $b)$ in the model denoted the unexplained variance associated with $X_{2}$ and $X_{3}$, respectively. The path analytic technique allowed computation (therefore an evaluation) of the magnitude of the relationship between IT sophistication and CBIS success which exists partly through MAI provision. A computation of the above relationship existing through the capacity allowed an evaluation of the mediating role played by the MAI provision. The model is represented below in equation form:

$$
\begin{aligned}
& X_{2}=P_{21} X_{1}+P_{2 a} R_{a} \\
& X_{3}=P_{31} X_{1}+P_{32} X_{2}+P_{3 b} R_{b}
\end{aligned}
$$

where:

$$
\begin{aligned}
& X_{1}=\text { IT sophistication } \\
& X_{2}=\text { MAI provision } \\
& X_{3}=\text { CBIS success }
\end{aligned}
$$

The path analysis required the running of two regression equations - one for MAI provision, and the other for CBIS success. The first equation treated MAI provision $\left(\mathrm{X}_{2}\right)$ as the dependent variable and IT sophistication $\left(X_{1}\right)$ as the independent variable. The results presented in

\begin{tabular}{|c|c|c|c|c|}
\hline & Variables & Regression Coefficient & $\mathrm{T}$ Value & Significance \\
\hline$X_{1}$ & IT Sophistication & 0.221 & 3.860 & 0.000 \\
\hline
\end{tabular}
Table 3 indicate a positive and significant relationship $\left(\beta_{1}=0.221 ; \mathrm{p}<0.01\right)$ between IT sophistication and MAI provision, thereby supporting hypothesis $\mathrm{H}_{2}$.

Table 3: Regression of MAI Provision $\left(X_{2}\right)$ Against IT Sophistication $\left(X_{1}\right)$

The second regression equation treated CBIS success $\left(X_{3}\right)$ as the dependent variable and MAI provision $\left(X_{2}\right)$ and IT sophistication $\left(X_{1}\right)$ as the independent variables. The results presented in Table 4 reveal positive and significant relationships between IT sophistication and CBIS success $\left(\beta_{1}=0.113 ; \mathrm{p}<0.05\right)$, and between MAI provision and CBIS success $\left(\beta_{2}\right.$ $=0.340 ; \mathrm{p}<0.01$ ), providing support for $\mathrm{H}_{1}$ and $\mathrm{H}_{3}$. A discussion on this result is offered in the next section. 
Table 4: Regression of CBIS Success $\left(X_{3}\right)$ Against MAI Provision $\left(X_{2}\right)$ and IT Sophistication $\left(\mathrm{X}_{1}\right)$

\begin{tabular}{lllll}
\hline & Variables & Regression Coefficient & T Value & Significance \\
\hline $\mathrm{X}_{2}$ & MAI Provision & 0.340 & 6.084 & 0.000 \\
$\mathrm{X}_{1}$ & IT Sophistication & 0.113 & 2.013 & 0.045 \\
\hline
\end{tabular}

$\mathrm{R}^{2}=0.146 ;$ Adjusted $\mathrm{R}^{2}=0.140 ; \mathrm{F}=24.444 ; \mathrm{p}<0.001$

The results presented in Table 3 and 4 were used to compute the magnitude of the direct and indirect relationships in the model. These results are presented in Table 5. Theoretically, the sum of the magnitudes of direct, indirect, and spurious (if any) relationships between two variables (say, $X_{1}$ and $X_{3}$ in Table 5) must be equal to the correlation between the same variables. The results presented in Table 5 indicate the presence of a positive relationship between IT sophistication and MAI provision $\left(X_{2}\right.$ with $\left.X_{1}\right)$; IT sophistication and CBIS success $\left(X_{3}\right.$ with $\left.X_{1}\right)$; and between MAI provision and CBIS success $\left(X_{3}\right.$ with $\left.X_{2}\right)$. Given the statistical significance and the positive direction of these relationships, the results indicated the presence of an indirect relationship between IT sophistication and CBIS success via MAI provision. In other words, the mediating role of MAI provision is supported.

Table 5: Decomposition of Correlations

\begin{tabular}{lrrll}
\hline $\begin{array}{l}\text { Combination } \\
\text { of Variables }\end{array}$ & $\begin{array}{l}\text { Observed } \\
\text { Correlation }\end{array}$ & $\begin{array}{l}\text { Direct } \\
\text { Impact }\end{array}$ & $\begin{array}{l}\text { Indirect } \\
\text { Impact }\end{array}$ & $\begin{array}{l}\text { Spurious Im- } \\
\text { pact }\end{array}$ \\
\hline X $_{2}$ with $X_{1}$ & $0.221=$ & 0.221 & & \\
$X_{3}$ with $X_{1}$ & $0.188=$ & $0.113+$ & $(0.221 * 0.340)$ & \\
$X_{3}$ with $X_{2}$ & $0.365=$ & $0.340+$ & & $(0.113 * 0.221)$ \\
\hline
\end{tabular}

\section{DISCUSSION, LIMITATIONS, AND CONCLUSIONS}

The main objective of this study was to examine empirically the mediating role of MAI provision in the relationship between IT sophistication and CBIS success. The results showed that increasing IT sophistication is associated with increasing MAI provision and CBIS success. The results also revealed that increasing MAI provision is associated with better CBIS. An explanation of the results is that as an organisation's IT sophistication increases, the availability of MA information to formulate, implement, and monitor its strategies would also increase. An outcome of the process is an improvement in CBIS success. 
This study extended prior research by offering an explanation for the relationship between IT sophistication and CBIS success. Many prior studies failed to report a significant direct relationship between IT sophistication and CBIS success. The results presented in Table 4 ( $\beta_{1}$ $=0.113)$ is statistically significant, hence contradicted with previous findings. Both hypotheses $\mathrm{H}_{2}$ and $\mathrm{H}_{3}$ are supported; thus supporting the fundamental argument put forward in this study. The proposition is that MAI provision plays a mediating role in the relationship between IT sophistication and CBIS success. For example, the positive and significant correlation $\left(r_{13}=0.188, p<0.01\right)$ between technological IT sophistication $\left(X_{1}\right)$ and CBIS success $\left(X_{3}\right)$ (Table 4$)$ is explained partly by the direct relationship $\left(\beta_{1}=0.113\right)$ between IT sophistication and CBIS success, and also the indirect relationship which exists through MAI provision $\left(\beta_{1}{ }^{*}\right.$ $\beta_{2}=0.221 * 0.340$, from Tables 3 and 4$)$. It is noted that about $40 \%(0.075)$ of the total relationship $\left(\mathrm{r}_{13}\right)$ is explained by the indirect relationship (see Table 5). This indicated the importance of the mediating role played by MAI provision in an organisation's attempt to improve its CBIS success. The finding also confirmed the argument put forward by many IS researchers that IT needs to be coupled with other organisational factors to have a greater impact on CBIS success. Bartol (1983) stated that a $\beta$ coefficient of the value of 0.06 or greater is important in explaining a relationship in a study using the path analysis technique. We considered that the magnitudes (coefficients) of the indirect relationship (0.075) and of the direct relationship (0.113) above are sufficient to be meaningful. This study also extended previous research on the role of MAI provision by incorporating CBIS success into the model. The importance of incorporating CBIS success (i.e. individual, system, and organisation) into the model in a study of the role of MAS had been emphasised in the literature.

Several limitations of the current study should be noted. Firstly, this study used a subjective orientation to measure MAI provision. Future research could employ a more objective approach by asking respondents about the applicability of specific MA techniques. A second limitation of this study is related to the sample, which covers only manufacturing firms with between 20 and 150 employees. Generalising the results to other industries (such as the service industry) should be done cautiously. Ideally, similar studies should be conducted with SMEs in other environments. Thirdly, the path model implies causality. This study is unable to assess the possibility that CBIS success affects MAI provision or MAI provision affects IT sophistication (i.e. the opposite causal direction). Finally, the study was based on a survey. This approach has 
shortcomings as it captures a situation or an event at a point in time. Future research could employ different research methodologies (e.g. longitudinal field studies) to overcome the limitations of a cross-sectional study.

Conditional upon the limitations described above, the study offered empirical support for Huber's (1990) theoretical argument that firms employing sophisticated IT can benefit from using MA information for decision-making, Moreover, the study extended prior studies by explaining the mediating role of the MAI provision in the relationship between IT sophistication and CBIS success. As a conclusion, this study proposes that SMEs that employ sophisticated IT can generate sufficient management accounting information and thereby improve their CBIS.

\section{REFERENCES}

Al-Mushayt, O.S. (2000). An empirical investigation of factors influencing the successful treatment of organisational issues in information systems development. Unpublished doctoral dissertation, Loughborough University.

Bartol, K.M. (1983). Turnover among DP personnel: A causal analysis. Communications of the ACM, 26, 807-811.

Brecht, H.D., \& Martin, M.P. (1996). Accounting information systems: The challenge of extending their scope to business and information strategy. Accounting Horizons, 10(4), 16-22.

Chenhall, R.H., \& Morris, D. (1986). The impact of structure, environment, and interdependence on the perceived usefulness of management accounting systems. The Accounting Review, LXI (1), 16-35.

Cragg, P.B., King, M., \& Hussin, H. (2002). IT alignment and firm performance in small manufacturing firms. Journal of Strategic Information Systems, 11(2), 109-132.

Daft, R.L., \& Lengel, R.H. (1986). Organisation information requirements, media richness, and structural design. Management Science, 32(5), 554-571.

de Guinea, A.O., Kelley, H., \& Hunter, M.G. (2005). Information systems effectiveness in small business: Extending a Singaporean model in Canada. Journal of Global Information Management, 13(3), 55-70.

DeLone, W., \& McLean, E. (1992). Information system success: The quest for dependent variables. Information Systems Research, 3(1), 60-95.

Dillman, D.A. (1978). Mail and telephone surveys: The total design method. New York: John Wiley \& Sons. 
El Louadi, M. (1998). The relationship among organisation structure, information technology and information processing in small Canadian firms. Canadian Journal of Administrative Sciences, 15(2), 180-199.

Fuller, T. (1996). Fulfilling IT needs in small businesses: A recursive learning model. International Small Business Journal, 14(4), 25-44.

Huber, G.P. (1990). A theory of the effects of advanced information technologies on organisational design, intelligence, and decision making. Academy of Management Review, 15(1), 47-71.

Hunter, M.G., \& Long, W.A. (2002). Information technology and small business: Lessons from the entrepreneurial process. Paper presented at the Information Resources Management Association Conference (IRMA), May 2002, Seattle, Washington.

Hunter, M.G., \& Long, W.A. (2003). Adopting the entrepreneurial process in the study of information systems and small business. In G. Gingrich (Ed.), Managing IT government, business, and communities. Hershey, PA: IRM Press.

Hunton, J.E., \& Flowers, L. (1997). Information technology in accounting: Assessing the impact on accountants and organizations. Advances in Accounting Information Systems, 5, 3-34.

International Federation of Accountants. (2006). Micro-entity financial reporting: Perspectives of preparers and users. New York: Small and Medium Practices Committee, International Federation of Accountants.

Ismail, N.A., Abdullah, S.N., \& Tayib, M. (2003). Computer-based accounting systems: The case of manufacturing-based small and medium enterprises in the northern region of Peninsular Malaysia. Jurnal Teknologi, 39, 19-36.

Ismail, N.A., \& King, M. (2005). Firm performance and AIS alignment in Malaysian SMEs. International Journal of Accounting Information Systems, 6(4), 241-259.

Ismail, N.A., \& King, M. (2007). Factors influencing the alignment of accounting information systems in small and medium sized Malaysian manufacturing firms. Journal of Information Systems and Small Business, 1(1/2), 1-19.

Marriot, N., \& Marriot, P. (2000). Professional accountants and the development of a management accounting service for the small firm: Barriers and possibilities. Management Accounting Research, 11, 475-492.

Mauldin, E.G., \& Ruchala, L.V. (1999). Towards a meta-theory of accounting information systems. Accounting, Organisations, and Society, 24, 317-331. 
Mitchell, F., Reid, G., \& Smith, J. (2000). Information system development in the small firm: The use of management accounting. London: CIMA Publishing.

Perren, L., \& Grant, P. (2000). The evolution of management accounting routines in small businesses: A social constructive perspective. Management Accounting Research, 11, 391-411.

Pollard, C.E., \& Hayne, S.C. (1997). The changing face of information system issues in small firms. International Small Business Journal, 16(3), 70-87.

Porter, M.E. (1985). Competitive advantage: Creating and sustaining superior performance. New York: The Free Press.

Ravarini, A., Tagliavini, M., \& Buonanno, G. (2002) Information system check-up as a leverage development, In S. Burgess (Ed.), Managing information technology in small business: Challenges and solutions (6282). Hershey, PA: Idea Group Publishing, Hershey.

Raymond, L., \& St-Pierre, J. (2005). Antecedents and performance outcome of advanced manufacturing systems sophistication. International Journal of Operations and Production Management, 25(5/6), $514-533$.

Shin, N. (2001). The impact of information technology on financial performance: The importance of strategic choice. European Journal of Information Systems, 10, 227-236.

Temtime, Z.T., Chinyoka, S.V., \& Shunda, J.P.W. (2003). Toward strategic use of IT in SMEs: A developing country perspective. Information Management and Computer Security, 11(5), 230-237. 